\title{
The Removal of Salinity in a Reed Bed System Using Mangroves and Bacteria in a Continuous Flow Series Reactor
}

\author{
Tri Cahyo Puspaningrum ${ }^{1 *}$, Harmin Sulistiyaning Titah ${ }^{1}$ \\ 1 Department of Environmental Engineering, Faculty of Civil, Planning and Geo Engineering, Institut Teknologi \\ Sepuluh Nopember, Keputih, Sukolilo, 60111 Surabaya, Indonesia \\ * Corresponding author's e-mail: puspa230536@gmail.com
}

\begin{abstract}
The supply of clean water is a major environmental problem in some areas, which is possibly handled through the biodesalination technologies, a concept that involves separating the salt content, and reducing salinity, using bacteria and plants. This research therefore applied Avicennia marina (AM) and Rhizophora mucronata (RM) mangroves, in addition to Vibrio alginolyticus, in 12 reactor reed bed systems arranged in series (AM-RM) to attain a continuous flow. The evaluated salinity level was $20 \%$ and $25 \%$, obtained using artificial saline water. Meanwhile, the reed bed system, measuring $0.14 \mathrm{~m}^{3}(0.7 \times 0.5 \times 0.4 \mathrm{~m})$, comprises a filter layer component, which consists of sand and gravel, with a diameter of $1 \mathrm{~cm}$ and $2 \mathrm{~cm}$. This investigation was performed for 18 days, and samples were collected every 2 days, and the main parameters of salinity, $\mathrm{Na}, \mathrm{Cl}$ and the potassium ion concentration, electric conductivity and Colony Forming Unit (CFU), as well as the supporting parameters, including $\mathrm{pH}$ and temperature, were evaluated. The results showed a water discharge rate of $18 \mathrm{~mL} / \mathrm{min}$, and the addition of Vibrio alginolyticus, produced the best salinity level (90\%) on day 6 of operation. The outcome of the initial 25\% sample value, measured as $20.09 \%$ at the inlet, was reduced to $1.99 \%$ at the outlet, after treating with Rhizophora mucronata. This was within the range for brackish water, and the calculations using the final salinity values showed a Cl-content of $1129.47 \mathrm{mg} / \mathrm{L}$, while the best conductivity value was $3,485 \mathrm{mS} / \mathrm{cm}$. In addition, the highest selective media CFU was Log 5.6, observed in the Avicennia marina 25\% reactor, to which Vibrio alginolyticus was added. The supporting parameters of temperature and $\mathrm{pH}$ measured $30^{\circ} \mathrm{C}$ and a range of $6-8$, respectively. Therefore, the removal of salt from brackish water using the mangrove operation is assumed to continuously produce low salinity levels.
\end{abstract}

Keywords: bacteria, biodesalination, mangrove, reed bed system

\section{INTRODUCTION}

Water is an important resource for living things, which is often used in the agricultural and industrial development, as well as for the human needs. Furthermore, not all regions have good aquatic resources, as seen in coastal areas, river mouths, small islands and the middle of the ocean, known to lack clean sources, subsequently causing problems in fulfilling the demand. The increasing human population and technological progression of a country have been identified as a driving force towards the requisition for better supply, and a decline in the amount results from the incidence of the surface and ground water pollution. These scarcity-related problems have led to the search for other purification approaches, including the saltwater desalination treatment methods, for example, brackish water, which possesses lesser salinity by $(<35 \%$ ) (Yusuf et al., 2009). This ought to be converted into freshwater, consequently increasing the clean water availability. In addition, the term desalination generally refers to the removal of dissolved solids (Dewantara et al., 2018), and plants have been used as another alternative approach. This biodesalination process is classified into three main subfields, including bio-inspired, biomimetic and the use of living organisms (Taheri et al., 2016), often conducted using plants, e.g., 
mangrove as an intermediary media to reduce salinity. Specifically, mangroves are one of the main groups of the salt-resistant plants, known to thrive effectively under the highly saline environment in a variety of ways, including through the accumulation of osmolytes, exclusion of salt in the roots, and attraction through the air of plants, as well as the efficient capture into old leaves and/or skin (Parida and Jha, 2010). Furthermore, they have been reported as facultative halophytes, due to the inherent ultrafiltration systems, capable of filtering about $90 \%$ of the $\mathrm{Na}^{+}$ions from the surrounding seawater through roots. These species also show a high level of salt absorption, provides a long-lasting desalination ability with high absorption rate (Flower and Colmer, 2015).

In this research, brackish water was used as a source of artificial saline water to be treated with desalination, using the concept of combining filter media, Avicennia marina and Rhizophora mucronata mangroves, and the introduction of bacteria. In addition, the technology concerned with the use of bacteria is termed biological desalination or biodesalination, which refers to the use of roots to ensure clean product. Chimayati and Titah (2019) reported Avicennia marina and Rhizophora mucronata as hyper-accumulator plants for the $\mathrm{Na}$ and $\mathrm{Cl}$ ions, where the root serves the purpose of nutrient absorption, which subsequently facilitates the production of leaves; hence, an elevation in the salt content is expected (Saeni and Tanasale, 1999). The process used in this study utilizes the helobacterium, Vibrio alginolyticus, known to live in salt crystals, which thrives in the areas with high salility, and is resistant to radiation, which is added to the reactor reed bed system. This bacterium is able to grow and survive in the immersed root area of plants in water (Chimayati and Titah, 2019), with a $\mathrm{pH}$ of $4-9$, although $6.5-8.5$ or alkaline conditions of 9 were recognized as optimal.

Saline biodesalination is a technological concept that has not been widely adopted. It uses the reactors modified from reed bed systems, generally applied in constructed wetlands, and this study required the use of growing mangrove plants in a reactor. The procedure involves a combination of biological, physical and chemical processes, as the mangrove plants present at the beach or brackish water areas allegedly tend to ensure desalination, resulting from the adaptability to the environment.
Salinity is one of the parameters used to determine the ground and surface water quality, being a measure of the dissolved salt, recorded in grams per liter of seawater. In addition, the samples are classified into freshwater, with values $<0.5 \%$, saltwater within a range of $0.5-30 \%, 30-50 \%$ and $>50 \%$ (Purwanti et al., 2019).

The previous research conducted by Chimayati and Titah (2019), using the plant species Rhizophora mucronata and Avicennia marina, which specifically provides a distinct response to reduced salinity, shows the occurrence of the biodesalination process. Therefore, the growth of mangroves on the beach or in the areas with salt water is assumed to be capable of eliminating salinity, due to plant environmental adaption. Specifically, the root part of plants possesses the capacity to absorb nutrients for the enrichment of leaves, as the final purpose of absorption, which is considered in the reduction of salt levels in the desalination process (Kim, 2016). This procedure, according to the research by Salisbury and Ross (1995) is proficient in the modification of plant salt composition, due to the dominance of the chloride ions. This parameter was increased in the root tissue of all plants, following an increase in salinity, as the root serves as the initial site for the passive absorption required to overcome the variation in the salt concentration with the environment, subsequently maintaining balance.

The purpose of this research, therefore, was to determine the salinity removal in the reed bed reactor system as a method of biodesalination, using the Avicennia marina and Rhizophora mucronata mangroves in the reactor, with and without the addition of Vibrio alginolyticus. In addition, the treatment unit is arranged in series with continuous flow, applying the concept of up flow, anticipating the salinity concentration values for clean water.

\section{MATERIALS AND METHODS}

This research applied biodesalination with a reed bed reactor system, which was prepared based on the zoning of mangrove plants, adopting a series arrangement principle. In addition, the Avicennia marina plant was used, followed by Rhizophora mucronata. The treatment systems require planning, in terms of waste disposal, organic matter content, media depth, plant species 
and others, in order to control or regulate quality in the resulting wastewater (Suprihatin, 2014).

The steps in this research require a series of activities, aimed at facilitating the understanding and providing a more detailed explanation through the description of each work phase, explained as follows.

\section{Bacterial Preparation}

The Vibrio alginolyticus requirement in each reactor is $5 \%$ of the water holding capacity; hence, a total of $300 \mathrm{~mL}$ bacteria was used. In addition, the growth media adopted was TCBS, which was prepared by dissolving about 22.25 grams, alongside 8 grams of NB in sterile aquadest present in a $250 \mathrm{~mL}$ Erlenmeyer flask. Subsequently, the grown bacteria were removed from the Petri dish, and sterility was ensured in all breeding activities, followed by placing the broodstock in an incubator for 24 hours at $37^{\circ} \mathrm{C}$. These were then transferred to a sterilized NB media after growing, which was then shaken using an orbital shaker for 2 days, in order to obtain an OD value of 1 . This measurement was performed using the GENESYS 30 type spectrophotometer, and the resulting bacteria were poured on the sand media and stirred; then, the mixture was introduced to a reactor with a sand height of $10 \mathrm{~cm}$.

\section{Plants Preparation}

The mangrove plants used as test materials for biodesalination include Avicennia marina and Rhizophora mucronata within the age range of 3-5 months. In addition, the seedlings used were taken from Wonorejo Mangrove Ecotourism, Surabaya, and planted as deep as $10 \mathrm{~cm}$ in the sand media of the reactor. Therefore, saline water was added to attain a height of $\pm 10 \mathrm{~cm}$, followed by the introduction of glucose to obtain COD levels of $750 \mathrm{mg} / \mathrm{L}$, and then the plants were allowed to acclimatize for 2 weeks.

\section{The Artificial Saline Preparation}

The determination of the saline water concentration was conducted to ascertain the acceptable degree of salinity, although the previous studies showed the ability for Avicennia marina and Rhizophora mucronata to grow and survive in 30,000 mg/L (Titah (a) et al., 2019). Therefore, the optimal condition ascertained for both plant species in field application is $<30 \%$.
On the basis of a research by Pradipta (2016), a salinity range of $22-32$ is obtainable at the Wonorejo Mangrove Ecotourism location in Surabaya, and Vibrio species are halophilic bacteria with the capacity to thrive between $20-40 \%$ (Arisandi et al., 2017). Moreover, the limits used served as an environmental condition determinant for bacteria. According to Adel (2001), the amount and type of bacterial diversity tend to reduce, resulting from an increase in the salt concentration. Thus, based on these considerations, this study uses a range of $20 \%$ and $25 \%$.

According to Tan (1991), sodium chloride $(\mathrm{NaCl})$ is the dominant salt in the mangrove land. Therefore, artificial saline water was adopted in this research by using aquadest solution and $\mathrm{NaCl}$ pro-analysis MERCK USA, with the aim of obtaining the desired salinity level of $20 \%$ and $25 \%$. These were attained by using a total of $5370 \mathrm{~g}$ and $6712.5 \mathrm{~g}$, respectively.

\section{Reactor Preparation}

A total of 12 reactors were used, with the respective presence and absence of bacteria in 4 , while the remaining 4 reactors contained media. In addition, each unit composed of the following: gravel with a diameter to height ratio of $1 \mathrm{~cm}: 5 \mathrm{~cm}, 2 \mathrm{~cm}: 5 \mathrm{~cm}$, while the sand measured a height of $10 \mathrm{~cm}$. Moreover, saline water was added into the reactor up to a height of $10 \mathrm{~cm}$, comprising about $56 \mathrm{~L}$ in each varied salinity concentration. Furthermore, the reactor used had a dimension of $0.7 \times 0.5 \times 0.4 \mathrm{~m}$, and was made of fiberglass, which is a strong corrosion resistant material (Sunyoto et al., 2016). Figure 1 illustrates the reed bed system, and the code names for each unit are shown in the following explanation:

- AMVA 25 - RMVA 25 : Avicennia marina + Vibrio alginolyticus 25\% - Rhizophora mucronata + Vibrio alginolyticus 25\%

- AM 25-RM 25 : Avicennia marina 25\% - Rhizophora mucronata $25 \%$

- BK1 25 - BK2 25 : Control 1 25\% - Control $225 \%$

- AMVA 20 - RMVA 20: Avicennia marina + Vibrio alginolyticus 20\%o - Rhizophora mucronata + Vibrio alginolyticus 20\%

- AM20-RM 20:Avicennia marina 20\%o-Rhizophora mucronata $20 \%$

- BK1 20 - BK2 20 : Control 1 20\% - Control $220 \%$ 
In this research, the reactors used were arranged in series. The initial flow served as an inlet in a continuous flow. Figure 2 shows the biodesalination process.

\section{Sample Testing Method}

Sampling was conducted every 2 days during the biodesalination process, and parameter measurement, including salinity, $\mathrm{Na}, \mathrm{Cl}$, and $\mathrm{K}$ ions, $\mathrm{pH}$, temperature and electrivity were performed on days $0,2,4,6,8,10,12,14,16$ and 18 . The samples tested were obtained at the inlet and outlet, using standards that were based on the testing method and the tools used and then each parameter was determined with 2 replications. Conversely, $60 \mathrm{~mL}$ of waste sample was taken, and the $\mathrm{pH}$ measurement conducted using Singapore's Senz $\mathrm{pH}$ portable digital $\mathrm{pH}$ meter, while salinity, temperature and conductivity were evaluated with the OHAUS Starter 3100C Conductivity Bench USA.

The determination of the bacterial population required the Colony Form Unit method (Harley and Prescott, 2002), which was calculated by assessing the number of colonies sampled and multiplied by the dilution factor. Hence, the outcome of the final dilution is expected to reach between 25 and 250 (Harley and Prescot, 2002).

The $\mathrm{Na}$ and $\mathrm{Cl}$ ion content was tested using Inductively Coupled Plasma (ICP) method, while Iodometric was adopted in the evaluation of the potassium ions. These evaluations were conducted on the samples with the most stable salinity removal outcome.

Some other parameters were also measured in each part of the plant (roots, stems and leaves), including fresh weight evaluation, which was perforemed as soon as possible, after collecting the samples from the reactor. These were then dried in an oven at $105^{\circ} \mathrm{C}$ for 24 hours to obtain the value for dry weight.

The data was statistically processed using the IBM Statistics SPSS 20. Descriptive analytical approach was applied to determine the responses to the declining salinity concentration that result from the influencing factors. Therefore, the evaluations were perfomed using analysis of variance (ANOVA) at 5\% significant difference (Riyanto, a)

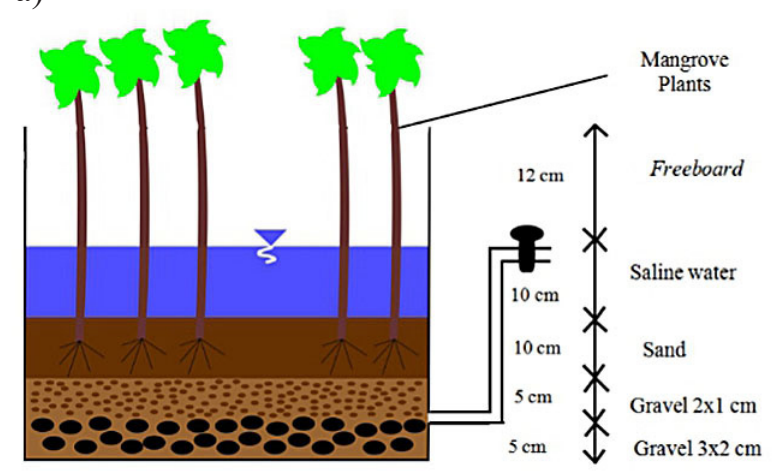

b)

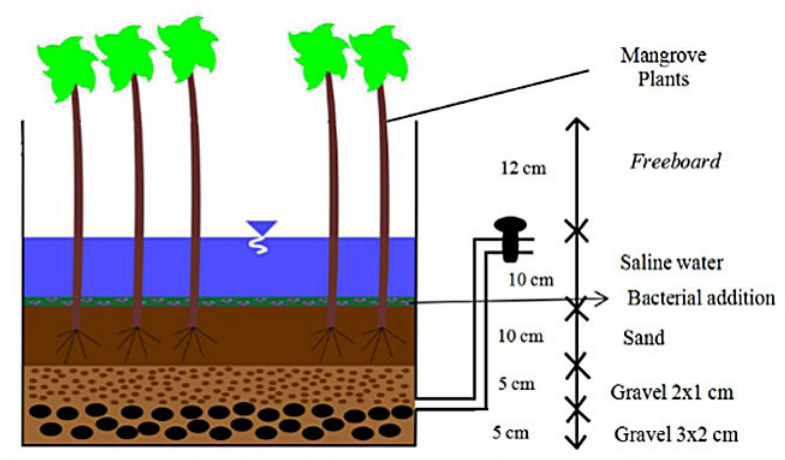

Figure 1. Reed bed reactor system (a) without addition bacteria and (b) with addition bacteria

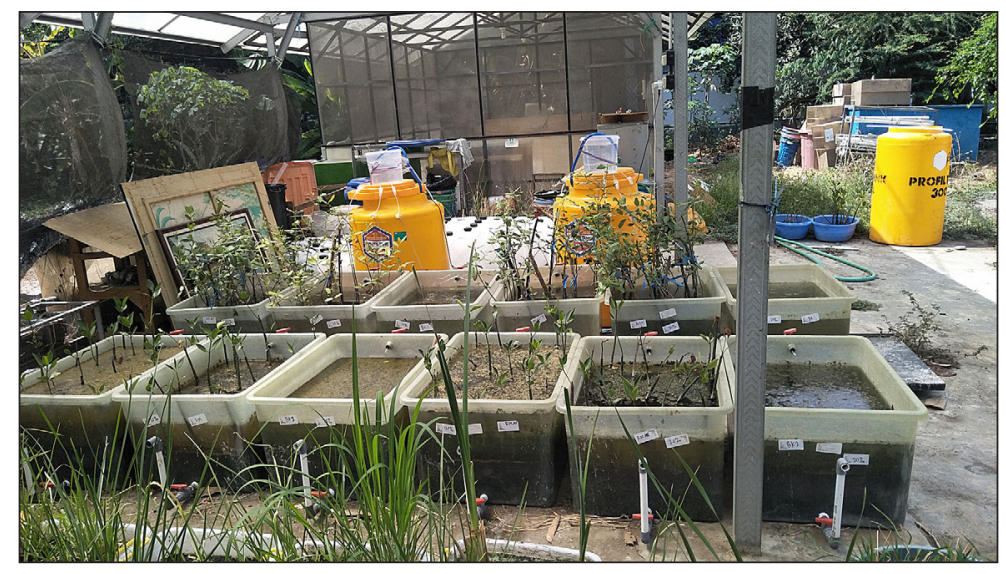

Figure 2. Reed bed system biodesalination reactor 
2009), in order to determine the effect of tested variations on the salinity elimination efficiency, using a $95 \%$ confidence level. Hence, lesser values with $\alpha=0.05$, are indicative of an acceptable proposed hypothesis. Furthermore, the ANOVA used 3 variables, including the addition and elimination of bacteria, as well as variation in the salinity concentration and sampling time.

\section{RESULTS AND DISCUSSION}

\section{Salinity Removal}

The effluent used is the resulting liquid obtained at the outlet with salinity removed after treating the saline water introduced at the inlet. The equation used during processing is as follows (Wang and Smith, 1994) with measurement in \%o:

$$
\% \text { Efficiency }=\frac{\text { inlet }- \text { outlet }}{\text { inlet }} \times 100 \%
$$

The outcome of biodesalination, using mangrove plants and bacteria for 18 days at a salinity level of $20 \%$ and $25 \%$ o demonstrated a level of fluctuation. However, all test samples showed a decline in salinity at the outlet after treatment.

This effect was observed in both reactors with plants and in the control. In addition, the treatments with the addition or absence of bacteria showed minimal difference; hence, the biodesalination system was confirmed to work properly under both conditions. During processing, the bacteria used possess the capacity to grow in the salty environment; hence Vibrio alginolyticus is identified in the reactor, without the manual addition. Furthermore, nutrients are added to mangrove by applying fertilizer and glucose to the plant growing media, with the aim of stimulating productivity and increased plant tissue nourishment (Feller et al., 2013). This process is perfomed by forming a mixture on the sand media, which is then stirred to ensure proper mixing. Meanwhile, the conditions for decreasing salinity are shown in Figure 3.

The results for all samples showed the optimal salinity decline points between days $0-6$, which occured in the biodesalination reactors containing only plants, and also with the addition of bacteria. This effect results from the capacity for plant roots to capture the minerals present in the saline water, expecially with the assistance of bacterium, which ensure proper absorption, although Avicennia marina is more effective than Rhizophora mucronata. This is congruent with the result of Scholander et al. (1968), demonstrating the ability for Avicennia marina to extract relatively higher ion concentration (Scholander $e t$ al., 1968). Furthermore, the salt levels regulation is also ensured by the removal through glands, because of the uptake as a nutrient for growth. According to Masduqi and Assomadi, (2012), $\mathrm{NaCl}$ present in artificial saline water dissolves to form the $\mathrm{Na}+$ and $\mathrm{Cl}$ - ions, where the soluble fractions are used up as a source of nourishment in the mangrove developement process. This is in line with the study by Sutcliffe and Baker (1975), where the addition $\mathrm{NaCl}$ stimulated the plant growth. Conversely, Rhizophora mucronata possess the capacity to excrete salt by means of root ultra-filtration, and not through leaves (Hegemayer, 1997 in Titah (a) et al., 2019). This technique involves separation using plant membrane pores, which occurs when water penetrates stems and roots. Therefore, the main mechanism of pollutant mopping, involves the bacterial transformation and physical-chemical processes, which

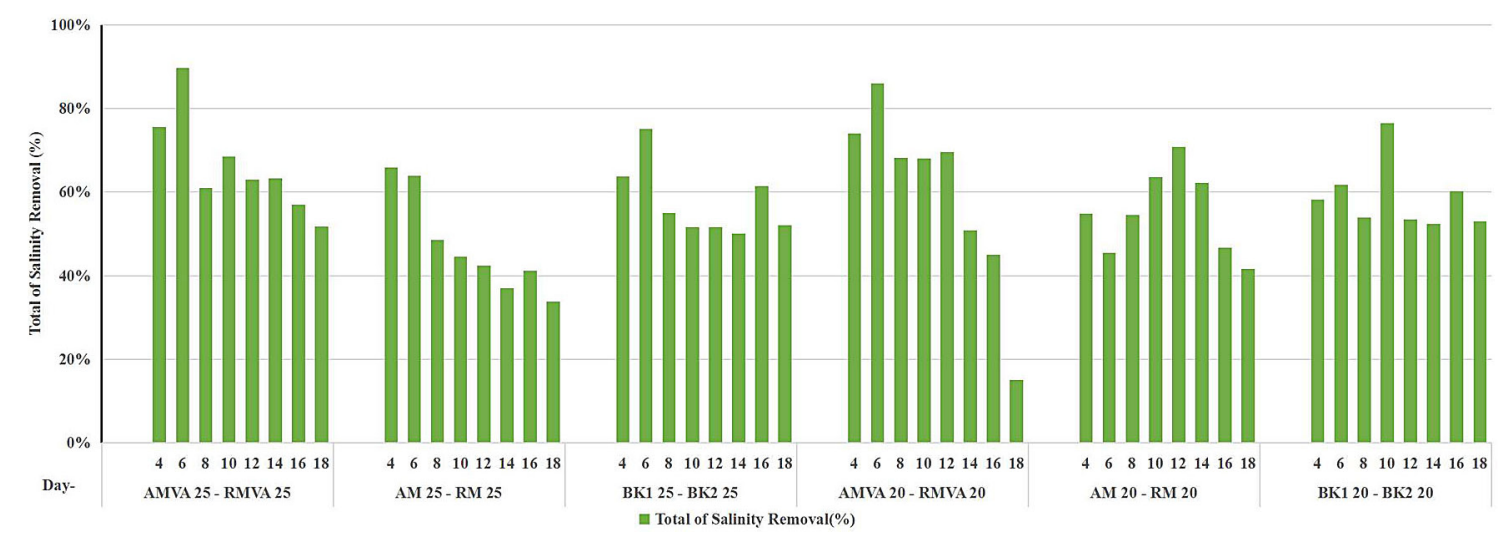

Figure 3. Percentage of salinity removal 
include adsorption, precipitation and sedimentation in the soil and rhizosperes of the root zone (Wong, 1997).

There was a decline in the level of salinity at the outlet, compared to the inlet, which indicates the proper functioning of the reed bed system reactors. In addition, the filters used during biodesalination tend to accumulate salt, and the mangrove root unit holds the remainder in the sand media. This leads to the production of cleaner content at the outlet, denoting a substantial level of effectiveness.

The reactor was also observed to function optimally without the addition of bacteria, as the control demonstrated a fairly high decline in salinity, indicating the effectiveness of the biodesalination tank filters. Moreover, the reactors with initial salinity of 25 "with a flow from Avicennia marina to Rhizophora mucronata had the best salinity elimination on day 6 , measuring 1.99 ". This was then included in the low-level brackish water category, with a fairly stable total removal percentage. Furthermore, there were no significant changes between the highest and lowest concentration values, therefore confirming the proper functioning of bacteria in assisting the root during pollutant absorption. This is observed in the reactors containing a combination of plants and bacteria, which led to about $90 \%$ decline in salinity. Additionally, the percentage removal is influenced by the nature of the working system, as the reed bed reserves the salt content.

The reduction observed at the beginning of treatment results from the high complexity of the removal process. Noor (2007) suggested the possible experience of filtration, sedimentation and absorption in the saline water, which occur due to the symbiotic relationship between the microorganisms and plant roots. Therefore, a combination of physical, chemical and biological processes ensures complete removal; hence a longer process duration leads to a greater elimination percentage with respect to time, as seen from the graph. This phenomenon takes place because the filter media used experiences saturation, subsequently causing the ions influencing saturation to saturate (Apriani et al., 2010).

According to Kusumastuti, (2009), the performance of the reed bed system reactors in the removal of pollutants with mangroves involves three methods, including (1) absorption into the roots, stems and leaves, (2) sedimentation in sediments assisted by the dense roots, and (3) the indirect function as a place for living bacteria to decompose pollutants. Furthermore, the absorption effectiveness is known to be influenced by the density of each plant in the individual reactor, which is not possible to determine. Therefore, this research used a range of 21 plants, which must be present to ensure the reduction of the desired pollutants.

The ability of the Rhizophora mucronata plant is observed in the physical characteristics evaluated during biodesalination. The results showed the tendency for some to experience wilting of leaves, with stems becoming black, soft, and smaller, which indicates the occurrence of salt absorption. Meanwhile, one of the physiological mechanism capabilities involves the collection of salt from the almost fallen dead bark and leaves (Kusumastuti, 2009).

Successful biodesalination was confirmed with the decline in the salinity concentration observed with and without the addition of bacteria to mangrove, as well as in the control tub. This activity is demonstrated by the percentage pollutant removed from the sample wastewater (Widayati, 2009).

On physical observation, Rhizophora mucronata shows wilting of leaves, and also the stems became blackish, softer, and smaller, which indicates salt absorption. Conversely, the most probable physiological mechanisms involves accumulation, identified in the almost fallen dead bark and leaves, which is obtained through the root cells, followed by an accelerated salt release through the leaf glands (Kusumastuti, 2009).

\section{Temperature}

The average temperature for saline water was $30^{\circ} \mathrm{C}$, fulfilling the requirement for bacteria to breed properly, and consequently treat wastewater. This is confirmed by the survival, growth and development tendencies observed at certain limits, as Vibrio alginolyticus thrives optimally between $30-35^{\circ} \mathrm{C}$, below $4{ }^{\circ} \mathrm{C}$ and at $45^{\circ} \mathrm{C}$ leading to the growth inhibition, and death has been reported at $55^{\circ} \mathrm{C}$ (Prajitno, 2007). Based on Farid and Larsen (1981), the growth of Vibrio alginolyticus showed the regular growth at high temperature $\left(42{ }^{\circ} \mathrm{C}\right)$. Meanwhile, the values recorded in the reactors used had minimal variations, resulting from the close proximity to one another, receiving similar supply of sunlight, as shown in Fig. 4. 


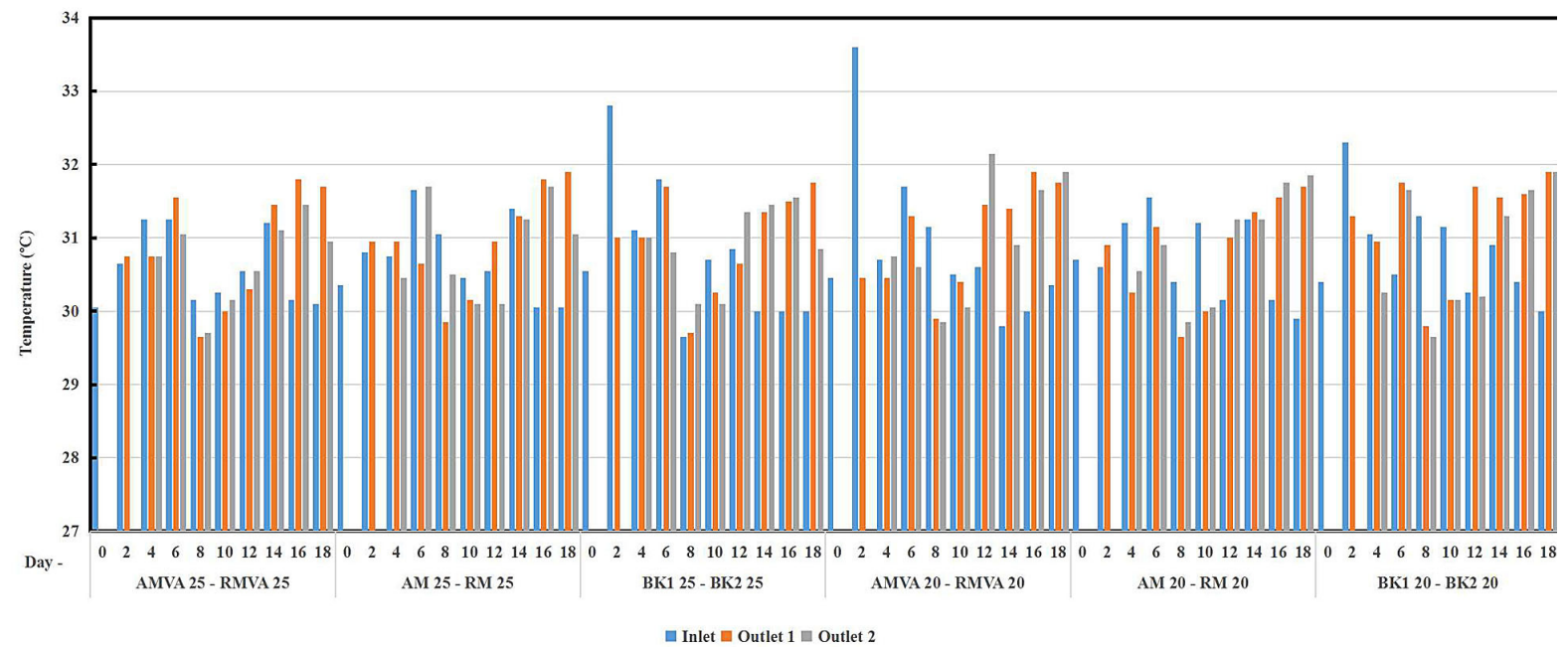

Figure 4. The temperature in the biodesalination process

$\mathrm{pH}$

The $\mathrm{pH}$ and temperature levels are major determinants of biodesalination, known to affect the rate of additional bacteria growth. In addition, the normal value for $\mathrm{pH}$, which is the measure of acidity or basicity of a liquid, is 6-8, while the record for water depends on the type of discharge (Fardiaz, 1993). Furthermore, the conditions at the time of sampling for all reactors were almost neutral within the 18 days of research, as shown in Figure 5. On the basis of the chart, a range of 5.8-8.1 was observed, with fluctuations in each reactor. These phenomenon possibly results from the microorganism activity (Titah (b) et al., 2019), because bacteria are attributed as living things in times of the biochemical processes that require enzymes. In addition, each species necessitate an optimum $\mathrm{pH}$ for development, and value required for mangrove was between 7.0 and 8.5. Sumarsih (2003) reported on the general preference of of neutral $\mathrm{pH}(\mathrm{pH} 7)$ by most microbes.

\section{Electrical Conductivity}

Electrical conductivity is a numerical description of the ability for water to conduct electricity, which is possibly adopted as a physical characteristic to evaluate the extent of desalination (Saeni and Tanasale, 1999). This occurs based on the directly proportional relationship between the higher dissolution of ionizable salt and the elevation in conductivity values, stated in the units of $\mathrm{mS} / \mathrm{cm}$ (Chimayati and Titah, 2019). Therefore, it

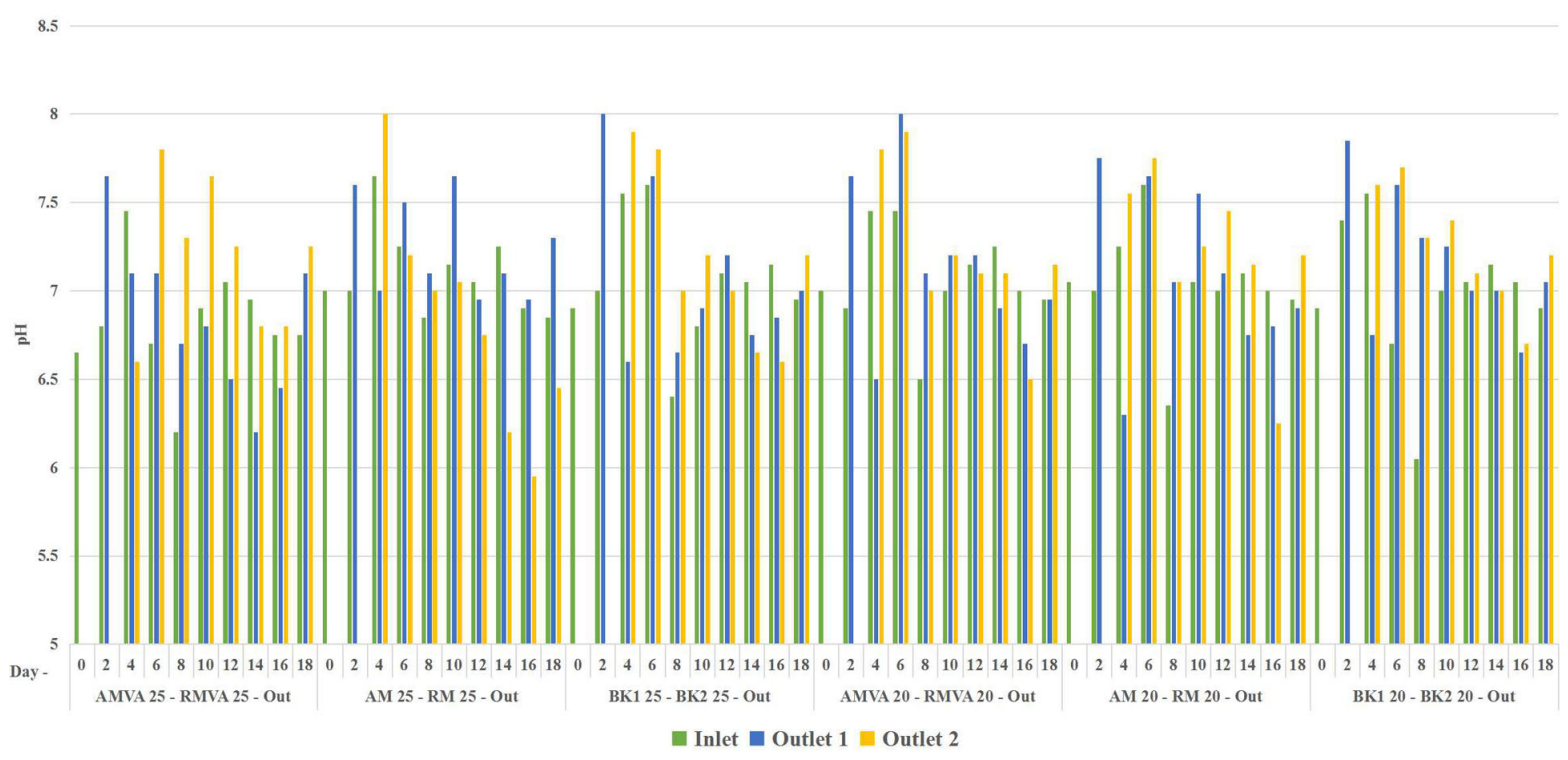

Figure 5. The $\mathrm{pH}$ in the bio-desalination process 
is expected that the conductivity values become lower at the outlet after treatment. This is not entirely in line with the results measured, as some reactors showed higher conductivity, despite the low salinity.

The best outcome was obtained in the reactors with the Rhizophora mucronata, with Vibrio alginolyticus bacteria and 20\% salinity. In addition, the extent of hydraulic conductivity tend to also influence wastewater detention time, as sufficient interval of exposure provides better contact opportunities between the microorganisms, wastewater, and the released oxygen (Tangahu and Warmadewanthi, 2001). Therefore, the chart in Figure 6 confirmed the ability for conductivity to affect the salinity concentration.

\section{Analysis of CFU}

The calculations for bacterial colonies were performed to determine the amount present in the biodesalination reactor. This measurement is required to demonstrate the existence of microorganisms, in order to ascertain the influence of bacteria in removing the saline water pollutant load. This testing process was carried out in triplicates on days 0,10 , and 18 . Furthermore, the time interval is intended to serve as a means of evaluating the number at the initial, middle and terminal stages of biodesalination. The results show the absence of any significant differences in CFU of reactors with and without the addition of bacteria. Meanwhile, the TCBS media showed the highest number of colonies in the systems containing mangrove with the addition of bacteria, at $20 \%$ and $25 \%$ salanity levels. The calculations on day 0 obtained a CFU of $\log 6.8$ and 5.7, respectively, while the amount in the control was minimal. Furthermore, the inorganic ion content of artificial saline water, including $\mathrm{NaCl}$, is assumed to positively influence the bacterial population number. According to Chatterjee et al.

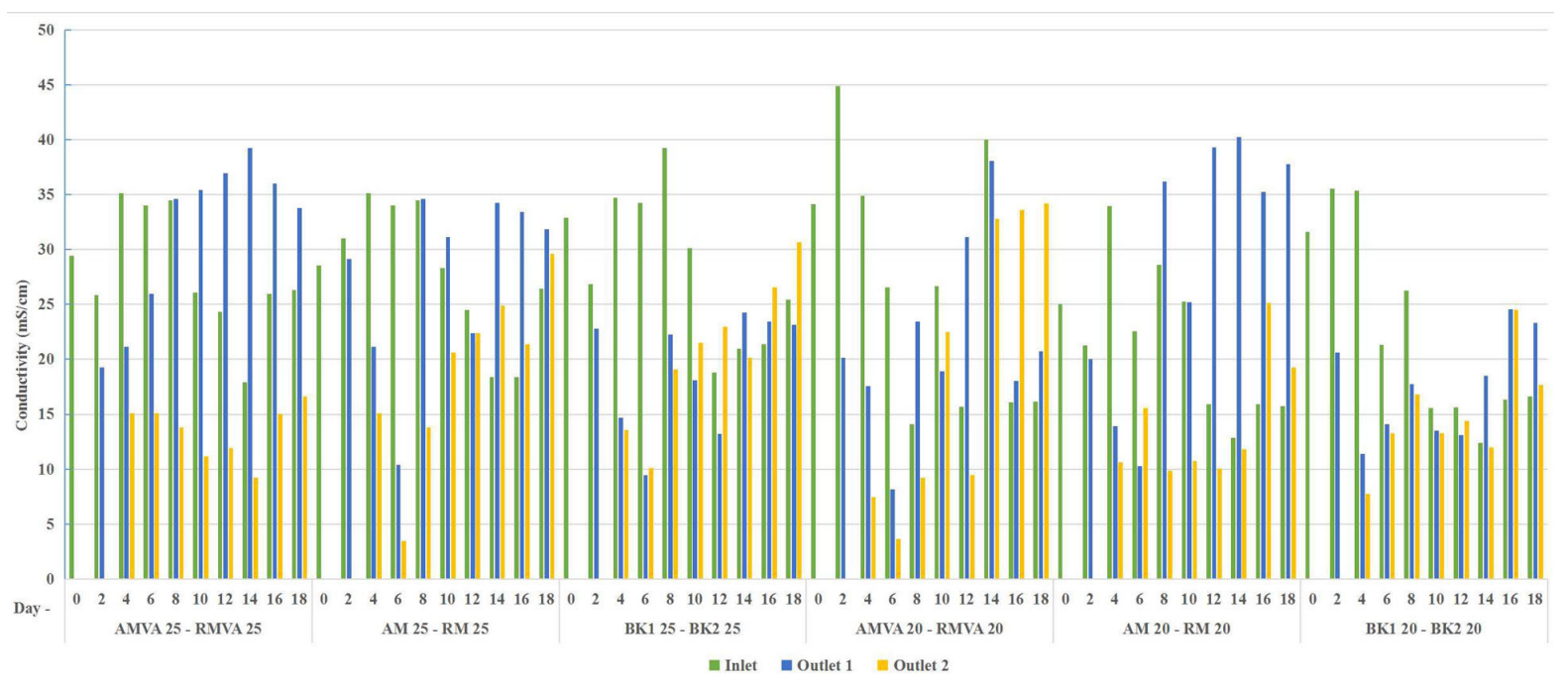

Figure 6. Conductivity in the biodesalination process

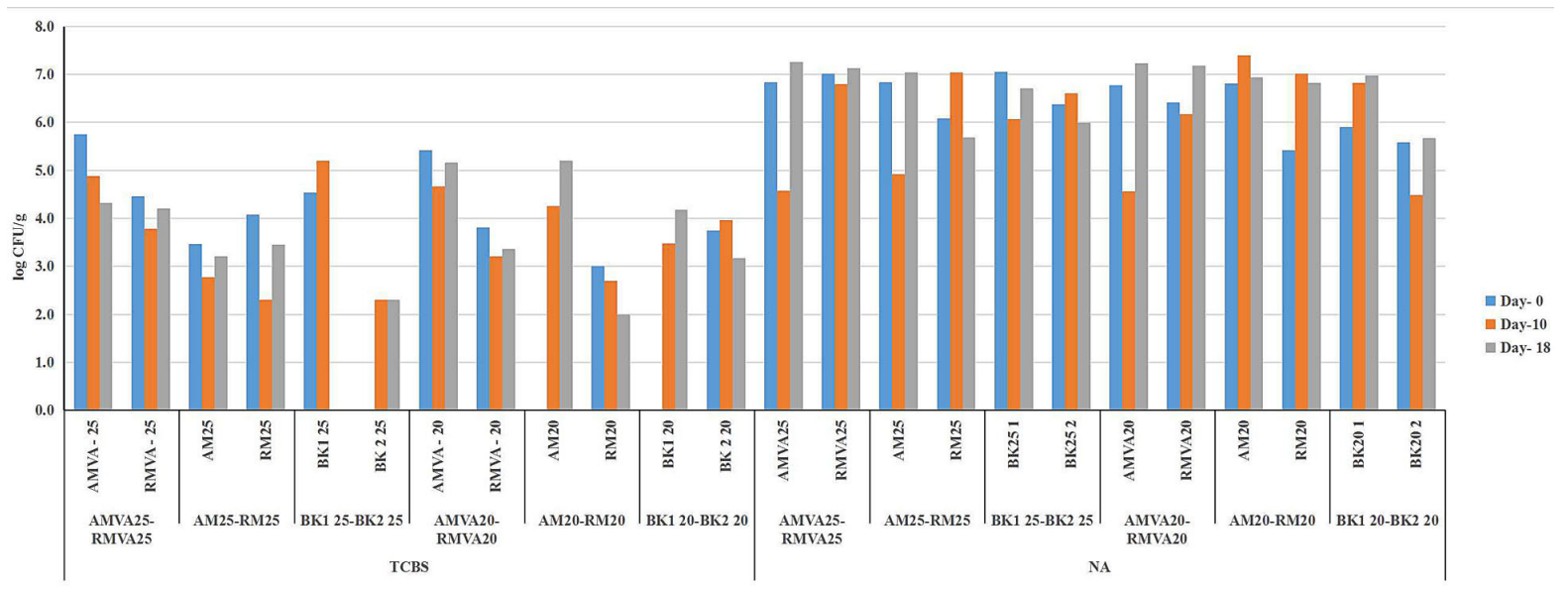

Figure 7. CFU in biodesalination process 
(2014), the availabile sodium salt is utilized by bacteria as an energy source for metabolism during cell formation, subsequently facilitating the daily increase in number, and Figure 7 demonstrates all calculation results.

\section{Fresh and dry weight}

The outcome of growth processes and the development of mangrove are possibly evaluated by the assessment of (1) fresh weight, as an accumulation of the material produced during growth, needed to determine the sample biomass (Buntoro et al., 2014), and (2) dry weight, which according to Gardner et al. (1991) results from the net accumulation of the $\mathrm{CO}_{2}$ assimilation through the growing season, which reflects the successfully synthesized organic compound aggregate from inorganic elements (particularly water and $\mathrm{CO}_{2}$ ). Figure 8 demonstrates the measurement results.

The combination of the Avicennia marina plants and Vibrio alginolytius bacteria at a salinity concentration of $25 \%$ demonstrated the most significant fresh weight, compared to other plants on day 18 , at 69.26 grams, although the dry weight at 24.03 grams was not too high. Conversely, the outcome of Rhizophora mucronata was higher at $25 \%$, indicating a superior level of effectiveness, as enhanced plant growth is considerably increased the fresh weight and accumulation of dry matter (Nurdin, 2008).

The variation in the results of dry weight is influenced by the fresh weight and also the number of leaves. This plays a major role in plant photosynthesis; hence, a higher quantity promotes the movement of organic compounds to various organs. Conversely, changes are also observed in the physical conditions on termination of biodesalination, including the leaf quality improvement, characterized by greener and thicker appearance. This outcome is in line with the report by Dwidjoseputro (1984), where the phenomenon was associated with the presence of excessive ion. The stability of the salinity concentration removal was greater in the reactors where Vibrio alginolyticus was added, hence tests were conducted with flow from Avicennia marina to Rhizophora mucronata in the presence of bacteria at $25 \%$.

\section{Concentration of $\mathrm{Na}, \mathrm{Cl}$ and $\mathrm{K}$ in saline water}

The results show a steady decline in the $\mathrm{Na}$, $\mathrm{Cl}$ and $\mathrm{K}$ ions from day 0 to 18 , also with a fluctuative increase, as shown in Figure 9. However, the differences between the amount of the $\mathrm{Na}$ and $\mathrm{Cl}$ ions indicates the occurrence of movement from water to plant media, through root ends. Meanwhile, both tend to function as constituents of physiological processes, as $\mathrm{Na}^{+}$plays a role in photosynthesis and the potassium ion exchange, while $\mathrm{Cl}^{-}$is absorbed during photosynthesis, and influences the osmotic pressure. The results show comparably lower concentrations in the reactors containing plants without bacteria, with the lowest $\mathrm{Na}^{+}$ and $\mathrm{Cl}^{-}$ion observed on day 4, at 2062.5 and $3134 \mathrm{mg} / \mathrm{L}$, respectively. These values indicate the presence of high potassium, which enter the plant after an exchange at the roots, where the highest value $(87.3 \mathrm{mg} / \mathrm{L})$ was measured on day 10, in the reactor without bacteria. Figs. 9 to 11 show the value for the $\mathrm{Na}, \mathrm{Cl}$ and $\mathrm{K}$ ions.

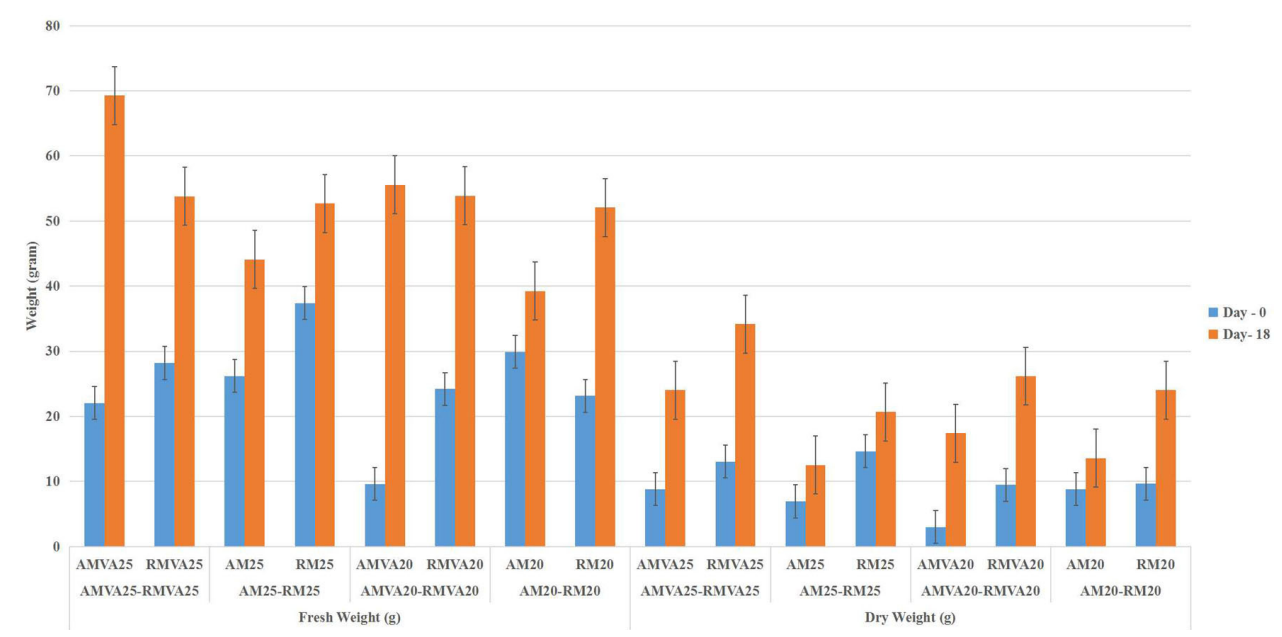

Figure 8. Fresh and dry weight measurement in the biodesalination process 


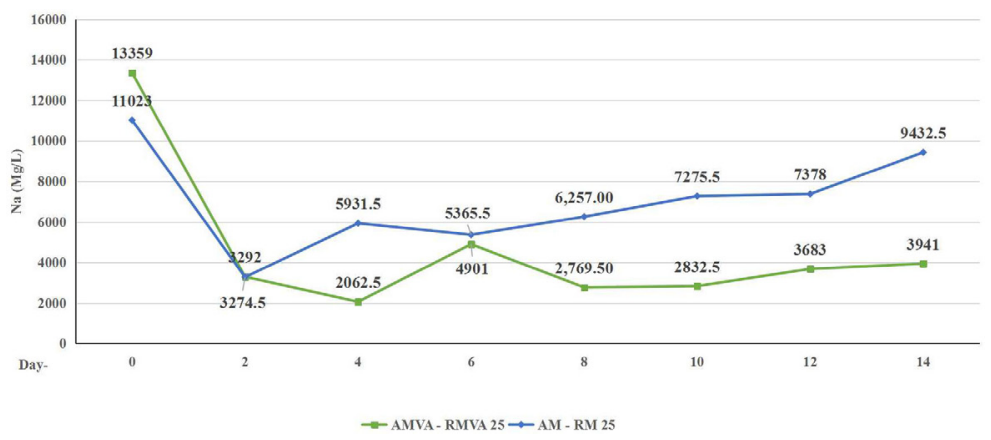

Figure 9. Test results of the $\mathrm{Na}^{+}$ion content in saline water

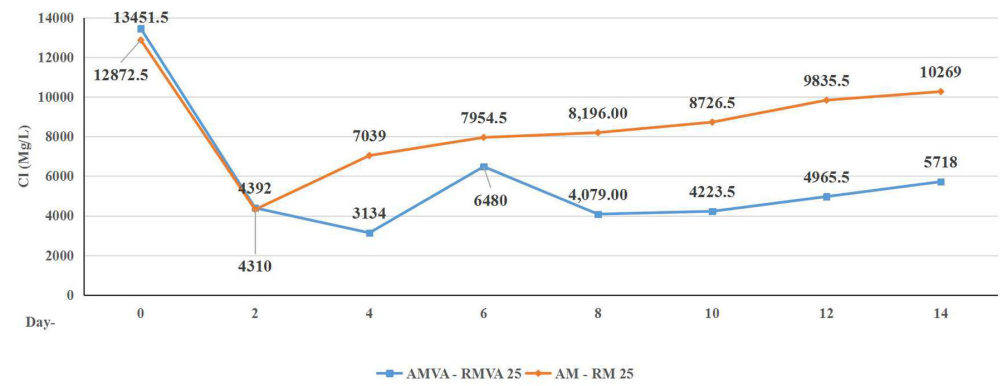

Figure 10. Test results of the $\mathrm{Cl}^{-}$ion content in saline water

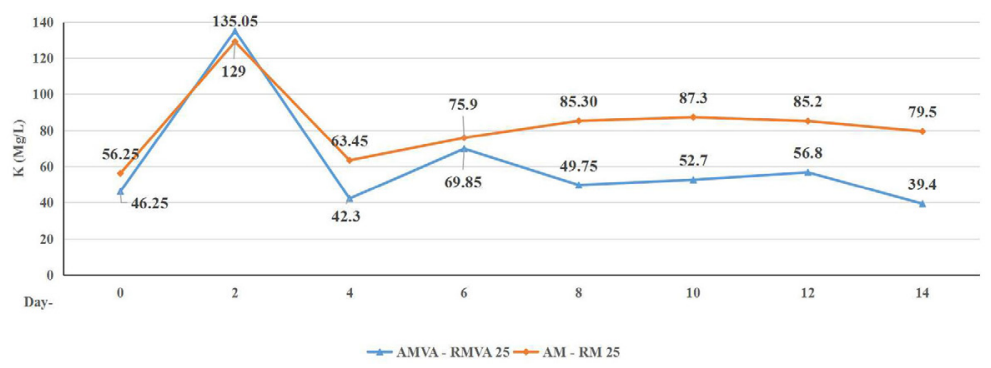

Figure 11. Test results of the $\mathrm{K}^{+}$ion content in saline water

\section{Statistic analysis}

On the basis on statistical evaluations, the presence and absence of the Vibrio alginolyticus bacterium produced significant results in the biodesalination reactor, in the aspect of salinity concentration removal and electrical conductivity. These parameters demonstrate the $\alpha$ values of 0.002 and 0.003 , respectively, indicating, a substantial impact on the treatment process. These results showed the presence of a directly proportional relationship between the salinity concentration and the conductivity values generated. Moreover, it was established that the plants with and without the addition of bacteria demonstrated the salinity reducing capabilities, which was relatively better in the reactors with microorganisms, where the first 6 days was identified as the optimal period. However, the influence of temperature and $\mathrm{pH}$, with $\alpha$ values of 0.836 and 0.459 , respectively, showed no significant differences under both conditions.

The salinity variable of $20 \%$ and $25 \%$, which represents low and high concentration, are observed in the brackish water area. On the basis of the statistical evaluation, the reported values significantly influenced the average outcome of both factors, including conductivity and salinity decline, which demonstrated the $\alpha$ values of 0.011 and 0.031 , respectively. The effects were established based on the differences between the inlet and outlet records. However, the differences between the average $\mathrm{pH}$ and temperature were not statistically significant, at $\alpha$ of 0.117 and 0.559 , respectively. These demonstrate a sig value of $>0.005$, indicating the absence of any influence on the salinity concentration variable. 
A variation in sampling time for all comparison factors, temperature, $\mathrm{pH}$, as well as the salinity reduction parameter were statistically significant at $\alpha=0.05$. Meanwhile, a longer treatment duration is associated with enhanced salt absorption, as a steady salinity decline was reported at the exponent of time.

\section{CONCLUSION}

The research on the saline water biodesalination using the mangrove plants and bacteria for 18 days at $20 \%$ and $25 \%$ salinity, showed fluctuations in the outcome. In addition, the best percentage decline occurred on day 6 , at $90 \%$, where the 25\% AMVA-RMVA sample was reduced to $1.99 \%$. Furthermore, the addition of Vibrio alginolyticus led to some significant differences, including the generation of more stable products.

\section{Acknowlegement}

The author would like to thank KemenristekDIKTI (Ministry of Research, Technology and Higher Education, Republic of Indonesia) through scheme of Penelitian Terapan Unggulan Perguruan Tinggi - second year research, PDUPT 2019 for funding this research with No of contract, 5/ E1/KP.PTNBH/2019 and No. 920/PKS/ITS/2019.

\section{REFERENCES}

1. Yusuf, E., Rachmanto, T.A. dan Laksmono, R., 2009, Pengolahan Air Payau Menjadi Air Bersih dengan Menggunakan Membran Reverse Osmosis, Jurnal Ilmiah Teknik Lingkungan, 1, (1), 6-15.

2. Dewantara, I.G.Y., Suyitno, B.M. and Lesmana, I. G.E., 2018, Desalinasi Air Laut Berbasis Energi Surya Sebagai Alternatif Penyediaan Air Bersih, Jurnal Teknik Mesin (JTM), 7, (1), 1-4,

3. Taheri, R., Razmjoua, A., Szekelyb, G., Houc, J. and Ghezelbash, R., 2016, Biodesalination-On harnessing the potential of Nature's desalination processes, $11,(4), 1-19$.

4. Parida, A.K. dan Jha, B., 2010, Salt tolerance mechanisms in mangroves: a review, Trees, 24, 199-217.

5. Flowers, T.F. and Colmer, T.D., 2015, Plant salt tolerance: adaptations in halophytes, Annals of Botany, 115, 327-331.

6. Chimayati, R.L. and Titah, H.S., 2019, Removal of Salinity using Interaction Mangrove Plants and
Bacteria in Batch Reed Bed System Reactor, Journal of Ecological Engineering, 20, (4), 84-93.

7. Saeni, M.S. and Tanasale, M., 1999, Desalinasi Air Laut dengan Tanaman Mangrove, Universitas Pattimura, Ambon.

8. Purwanti, I.F. Anjasmara, I.R. and Suharmadi, 2006, Pemodelan Salinitas Air Tanah di Surabaya Timur, Prosiding Seminar Nasional Managemen Teknologi III, Jurusan Teknik Lingkungan-FTSLK, Institut Teknologi Sepuluh Nopember, Surabaya.

9. Kim, K., Seo, E., Chang, S.K. Jung, T. Park dan Sang, J.L., 2016, Novel water filtration of saline water in the outermost layer of mangrove roots, 1-9.

10. Salisbury, F.B. and Ross, C.W., 1995, Fisiologi Tumbuhan, Jilid 1, ITB, Bandung.

11. Suprihatin, H., 2014, Penurunan Konsentrasi BOD Limbah Domestik Menggunakan Sistem Wetland dengan tumbuhan Hias Bintang Air (Cyperus alternifolius), Dinamika Lingkungan Indonesia, 1, Issue. 2, 80-87.

12. Titah, H.S., Purwanti, I.F., Pratikno, H. Chimayati, R.L. and Handayanu, 2019(a), Preliminary Phytotoxicity Test on Salinity Against Mangrove Plants of Rhizophora mucronata, Journal of Ecological Engineering, 20, 3126-134.

13. Pradipta, N., 2016, Studi Kandungan Nitrogen (N) dan Posfor (P) Pada Sedimen Mangrove di Wilayah Ekowisata Wonorejo Surabaya dan Pesisir Jenu Kabupaten Tuban, Skripsi, Universitas Airlangga.

14. Arisandi, A., Wardani, M.K., Badami, K. dan Araninda, G.D., 2017, Dampak Perbedaan Salinitas Terhadap Viabilitas Bakteri Vibrio fluvialis, Jurnal Perikanan dan Kelautan, 9, (2),

15. Adel, M., 2001, Bacterial Decomposition of Avicennia marina Leaf Litter, Journal of Biological Science, 8, 717-719.

16. Tan, K.M., 1991, Dasar-dasar Kimia Tanah, UGM Press, Yogyakarta.

17. Sunyoto, Danang, D.S. and Suwahyo, 2016, Pengolahan Sampah Organik Menggunakan Reaktor Biogas di Kabupaten Kendal, Jurnal Rekayasa, 14(1), 29-36.

18. Harley, J.P. and Prescott, L.M., 2002, Laboratory Exercises in Microbiology Fifth Edition, McGrawHill Companies, Texas.

19. Riyanto, A., 2009, Pengolahan dan Analisis Data Kesehatan, Jazamedia, Yogyakarta.

20. Wang, Y.P. dan Smith, R., 1994, Design of Distributed Effluent Treatmnet System, Chemical Engineering Science, 49, 18, 3127-3145.

21.Feller, I.C, Chamberlain, A.H., Piou, C, Chapman, S., and Lovelock, C.E., 2013, Latitudinal patterns of herbivory in mangrove forests: Consequences of nutrient enrichment, Ecosystems, $16,1203-1215$. 
22. Scholander, P.F., 1968, How mangroves desaline seawater. Physiol. Plant., 21, 251-261.

23. Masduqi, A. and Assomadi, A.F, 2012, Operasi dan Proses Pengolahan Air, ITS Press, Surabaya.

24. Sutcliffe, J. dan Baker, D., 1975, Plant and Mineral Salt, Oxford and IBH Publishing, London.

25. Wong, Y.S., 1997, Mangrove Wetland As Wastewater Threatment Facility: A Field Trip, Hidrobiologia, 352, 49-59.

26. Noor, M., 2007, Rawa Lebak-Ekologi Pemanfaatan, dan Pengembangan, Raja Grafindo Persada, Jakarta.

27. Apriani, R.S. and Wesen, P., 2010, Penurunan Salinitas air Payau dengan Menggunakan Resin Penukar Ion, Envirotek: Jurnal Ilmiah Teknik Lingkungan. 2, 1, 64-77.

28. Kusumastuti, W., 2009, Evaluasi Lahan Basah Buatan Vegetasi Mangrove Dalam Mengurangi Pencemaran Lingkungan. Studi Kasus di Desa Kepetingan Kabupaten Sidoarjo, Tesis Ilmu Lingkungan Universitas Diponegoro, Semarang.

29. Widayati, K., 2009, Evaluasi Lahan Basah Bervegetasi Mangrove dalam Mengurangi Pencemaran Lingkunga (Studi Kasus di Desa Kepetingan Kabupaten Sidoarjo, Thesis Ilmu Lingkungan Universitas Diponegoro, Semarang.

30. Prajitno, A., 2007, The Sensitivity Test of Flavonoid, of Eucheuma cottoni With Different Concentration as Vibrio harveyi, In. Jurnal Protein, 15(2), 66-71.

31. Farid, A.F and Larsen, J.L, 1981, Growth of Vibrio alginolyticus: Interacting effects on $\mathrm{pH}$, temperature, salt concentration, and incubation time. Zentralblatt für Bakteriologie Mikrobiologie und Hygiene: I. Abt. Originale C: Allgemeine, angewandte und ökologische Mikrobiologie, 2(1), 68-75.
32. Fardiaz, S., 1992, Polusi Air Dan Udara. PT.Kanisius. Yogjakarta.

33. Titah, H.S., Purwanti, I.F., Pratikno, H., Chimayati, R.L. and Handayanu, 2019(b), Removal of Chemical Oxygen Demand in Brackish Water by Rhizophora mucronata using Reed Bed System Batch Reactor, E3S Web of Conferences 125.

34. Sumarsih, S., 2003, Mikrobiologi Dasar, Jurusan Ilmu Tanah Fakultas Pertanian Upn Veteran, Yogyakarta.

35. Tangahu, B.V. dan Warmadewanthi, I.D.A.A., 2001, Pengolahan Limbah Rumah Tangga dengan Memanfaatkan Tanaman Cattail (Typha angustifolia) dalam Sistem Constructed Wetland. Purifikasi, 2(3).

36. Chatterjee. P., Bagchi, S. and Sengupta, N., 2014, The non-uniform early structural response of globular proteins to cold denaturing conditions: a case study with Yfh1, The Journal of Chemical Physics, 141, 20, 1-13.

37. Buntoro, B.H., Rogomulyo, R. and Trisnowati, S., 2014, Pengaruh Takaran Pupuk Kandang dan Intensitas Cahaya Terhadap Pertumbuhan dan Hasil Temu Putih (Curcuma zedoaria L.), Vegetalika, 3, 4, pages. 29-39.

38. Gardner, F.P., Pearce, R.B. and Mitchell, R.L., 1991, Physiology of Crop Plants (Fisiologi tumbuhan Budidaya, alih bahasa Herawati Susilo). UI Press. Jakarta

39. Nurdin, Maspeke, P., Ilahude, Z., Zakaria, F., 2008, Pertumbuhan dan Hasil Jagung yang Dipupuk N, P dan K pada Tanah Vertisol Isimu Utara Kabupaten Gorontalo, J Tanah Trop, 14, 1, 49- 56.

40. Dwidjoseputro, D., 1994, Pengantar Fisiologi Tumbuhan, PT. Gramedia, Jakarta. 